\title{
Fletcher v. Security Pacific National Bank: Unfair Bank Practices and Consumer Class Actions
}

Fletcher v. Security Pacific National Bank ${ }^{1}$ arose from the dismissal of a class action for restitution of overcharges caused by defendant's statutory unfair trade practice in calculating annual interest on loans. The trial court reasoned that individual issues of fact and law would predominate at trial over common ones; in particular, each borrower would have to prove individual reliance on the defendant's misrepresentations as to the annual percentage rate of interest. The supreme court reversed, liolding that a trial court has discretion to order statutory restitution to class inembers regardless of individual reliance. The decision facilitates consumer class actions by modifymg the substantive basis for liability under the statutes prohibiting unfair trade practices, and suggests procedural innovations that could inake class recovery inore viable.

Part I of this Note examines the historical context of the case. Part II sets forth its facts and analyzes the rationale of the opinion. Part III discusses the public policy basis for the decision, and suggests that is the soundest justification for tlie court's decision. Part IV exannines and attempts to resolve soine practical probleins and other ramifications of the decision. Finally, Part V discusses problems regarding the maintenance of class and individual actions that the opinion leaves unresolved.

\section{I}

\section{Historical CONTEXT}

A recurrent problein in consumer fraud law in general lias been low to effect a reinedy when a misrepresentation injures numerous parties, for eacli of whoin the dainages are sinall, although the cumulative dainages inay be quite sizable. Many consumers never even detect the deceptive practice. Others cannot meet the traditional common law requireinent of proving reliance on the misrepresentation. Still otlers, who could prove a cause of action, do not sue because their potential recovery is not wortli the expense of bringing suit. The lack of an effective remedy results in the law inadequately deterring those who would misrepresent their products or services.

Class action suits have not proved as helpful in fraud actions as in

1. 23 Cal. 3d 442, 591 P.2d 51, 153 Cal. Rptr. 28 (1979) (Tobriner, J.) (4-3 decision). 
some other areas of consumer protection. ${ }^{2}$ Until recently, there was little chance of a class action for fraud getting beyond a motion to dismiss, ${ }^{3}$ since individual questions of fact and law, e.g., as to the representation and the consumer's reliance upon it, would be found to be so numerous as to make the class suit unmanageable. In Vasquez v. Superior Court, ${ }^{4}$ the supreme court allowed a class action for fraud to proceed by suggesting that individual reliance might be established by proving the existence of a pattern in sales training and materials, without requiring individual testimony. ${ }^{5}$ But Vasquez presented a rare set of facts, particularly favorable to maintenance of the class suit. ${ }^{6}$ It probably represents the outer limit of a maintainable class action for fraud. ${ }^{7}$ Hence, because the named plaintiff will not be able to prove individual reliance by the class members without each individual's testimony, consumer class actions will not be a viable remedy in nost common law fraud cases.

Even when a common law class action might be brought, the plaintiffs and their lawyers may well face a serious financial hurdle. Procedural due process inay require that plaintiff pay the substantial costs of giving notice of the suit to all those in the class. ${ }^{8}$ Additionally, class actions may be inappropriate in common law consumer fraud cases in which the class members are numerous. The likelihood of conflicting imterests among the class nembers will make named plaintiff's inanagement of the suit difficult. ${ }^{9}$

Consistent with a national trend "from an economic order that rested on maximum freedom for the private entrepreneur to one com-

2. See, e.g., Blackie v. Barrack, 524 F.2d 891 (9th Cir. 1975), cert. denied, 429 U.S. 816 (1976) (securities fraud action under rule 10b-5).

3. See Weaver v. Pasadena Tournament of Roses, 32 Cal. 2d 833, 198 P.2d 514 (1948) (dismissal of class action on behalf of those fraudulently denied admission to the Rose Bowl); Slakey Bros. Sacramento, Inc. v. Parker, 265 Cal. App. 2d 204, 71 Cal. Rptr. 269 (3d Dist. 1968) (dismissal of class action for fraudulent inducement to advance additional credit); Goodspeed v. Great W. Power Co., 19 Cal. App. 2d 435, 65 P.2d 1342 (3d Dist. 1937) (no class suit permitted under CAL. CIv. CODE $\S 1711$ when individual rights to recovery depend on different facts).

4. 4 Cal. 3d 800, 484 P.2d 964, 94 Cal. Rptr. 796 (1971).

5. Id. at 814,484 P.2d at 973,94 Cal. Rptr. at 805 .

6. The Vasquez complaint alleged that defendant charged unconscionable prices, had salespersons inemorize a standardized sales pitch, and that, from the nuateriahty of the misrepresentations contained in that pitch, an inference of rehance could be drawn. Id. at 810-14, 484 P.2d at 970-73, 94 Cal. Rptr. at 802-05. In effect, the conplaint alleged that each fraud was a carbon copy.

7. Cf. Baronoff, Comment on Vasquez v. Superior Court, 18 U.C.L.A. L. Rev. 1091, 1098 (1971) (Vasquez should be limited to its facts).

8. Eisen v. Carlisle \& Jacquelin, 417 U.S. 156 (1974) (class action dismissed when plaintiff could not pay notice costs). But see Cartt v. Superior Court, 50 Cal. App. 3d 960, 124 Cal. Rptr. 376 (2d Dist. 1975) (class action nuay be carried forward with less notice than Eisen requires, but the suit will not formally bind absent class nembers).

9. See, e.g., Gonzales v. Cassidy, 474 F.2d 67 (5th Cir. 1973). 
mitted to restraints upon that freedom," 10 the California legislature has over the years enacted a series of statutes to protect purchasers from the deceptive practices of unscrupulous businessmen. ${ }^{11}$

Business and Professions Code sections 17500 to 17535 , adopted in 1941 , recodified and combined earlier legislation aimed at unfair business practices. ${ }^{12}$ Section 17500 provides tlie substantive basis for liability. ${ }^{13}$ Section 17535 concerns remedies, and until 1972 it read as follows:

Any person, corporation, firm, partnership, joint stock company, or any other association or organization which violates or proposes to violate this chapter may be enjomed by any court of competent jurisdiction.

Actions for injunction under this section may be prosecuted by the Attorney General or any district attorney in this state in the name of the people of the State of Califorma upon their own complaint or upon the complaint of any board, officer, person, corporation or by any person acting for the interests of itself, its inembers or the general public. ${ }^{14}$

In 1972 a second sentence was added to the first paragraph of section 17535, declaring:

10. Kadish, Some Observations on the Use of Criminal Sanctions in Enforcing Economic Reg. ulations, 30 U. CHI. L. REv. 423, 425 (1963).

11. The earliest legislative treatment was in PENAL CODE $\$$ 654(a), enacted 1905 Cal. Stats., ch. $254, \S 1$, at 227 (repealed), refiecting outmoded beliefs that behavior modification was best achieved through the criminal law. See Kadish, supra note 10, at 440-47. To judge from the lack of reported appellate decisions, prosecutions seem to have been few. This could be explained by the often cited lack of state resources to prosecute less important crimes, see note 17 infra, and by the lesser degree of antipathy by prosecutors and juries toward certain types of conduct, among them many victimless and white collar crimes. See Kadish, supro note 10, at 444-46.

In 1933, the legislature substantially amended CIV. CODE $\$ 3369$ to allow the Attorney General or any district attorney to enjoin any act of unfair competititon, which was defined to include unfair or misleading advertising. $1933 \mathrm{Cal}$. Stats., ch. $953, \$ 1$, at 2482 . All the prosecuting attorney had to prove was that the advertising was misleading, without any requirement of showing defendant's knowledge, or even what a reasonable defendant would have known.

12. Compare 1941 Cal. Stats., ch. 63 , \& 1, at 727, with 1915 Cal. Stats., ch. $634, \S 1$, at 1252 and 1933 Cal. Stats., ch. $953, \S 1$, at 2482.

13. CAL. Bus. \& Prof. Code $\$ 17500$ (West Supp. 1979) provides, in part:

lt is unlawful for any person, firm, corporation or association, or any employce thereof with intent directly or indirectly to dispose of real or personal property or to perform services, professional or otherwise, or anything of any nature whatsoever or to induce the public to enter into any obligation relating thereto, to make or disseminate or cause to be made or disseminated before the public in this state, in any newspaper or other publication, or any advertising device, or by public outcry or proclannation, or in any other manner or means whatever, any statement, concernimg such real or personal property or services, professional or otherwise, or concerning any circumstance or matter of fact connected with the proposed performance or disposition thereof, which is untrue or inislcad$\mathrm{mg}$, and which is known, or which by the exercise of reasonable care should be known, to be untrue or misleadimg, or for any such person, firm, or corporation to so make or disseminate or cause to be so made or disseminated any such statement as part of a plan or scheme with the imtent not to sell such personal property or services, professional or otherwise, so advertised at the price stated therein, or as so advertised.

14. 1941 Cal. Stats., ch. $63, \S 1$, at 729. 
The court may make such orders or judgments, including the appointment of a receiver, as may be necessary to prevent the use or employment by any person, corporation, firm, partnership, joint stock company, or any other association or organization of any practices which violate this chapter, or which may be necessary to restore to any person in interest any money or property, real or personal, which may have been acquired by means of any practice in this chapter declared to be unlawful. ${ }^{15}$

Section 17535 thus gives both a public remedy and a private one. Unfortunately, while public prosecutions might go far to meet the deterrence goal, and perhaps even the compensation goal, ${ }^{16}$ the state has not had sufficient resources to prosecute a large number of public actions. ${ }^{17}$

The central problem in Fletcher was whether to interpret the private remedy under section 17535 in such a way as to lower the traditional barriers for redress of alleged consumer fraud. Specifically, the court had to decide if the proper interpretation of the pre-1972 statute, under which Fletcher arose, permitted a trial court to order restitution to consumers who did not individually prove that they were unaware of the nature of defendant's unfair trade practice. The statute, if so interpreted, would allow the maintenance of class actions that could not have been brought under the common law, significantly increasing consumer protection by subjecting businesses employing deceptive practices to a credible threat of class liability.

II

\section{THE OPINION}

\section{A. The Facts of the Case}

Plaintiff Fletcher took a short-term commercial loan froin defendant bank, and signed a promissory note stating the interest rate to be seven and a quarter "per cent per annum." Fletcher was unaware that the interest rate was calculated on the basis of the $365 / 360$ method, ${ }^{18}$

15. 1972 Cal. Stats., ch. $244, \S 1$, at 494 (emphasis added). Also, a provision allowing city and county attorneys to bring the action was added to the second paragraph. Id., ch. $711, \S 3$, at 1300.

16. See, e.g., People v. Pacific Land Research Co., 20 Cal. 3d 10, 19 \& n.9, 569 P.2d 125, 130 \& n.9, 141 Cal. Rptr. 20, 25 \& n.9 (1977).

17. Vasquez v. Superior Court, 4 Cal. $3 d$ at 817 n.14, 484 P.2d at 974 n.14, 94 Cal. Rptr. at 806 n.14.

18. Three different methods of calculating "per annum" interest rates exist. The $365 / 365$ method is calculated by dividing the stated interest rate by 365 to obtain the daily rate: the interest due on the loan is then the product of daily rate times principal times number of days in the payment period. The $360 / 360$ method calculates the daily rate by dividing the stated rate by 360 ; the interest due is calculated the same way, except that each month is treated as if it had thirty days. Both these methods, over the course of a year, will yield exactly the stated interest rate. Comment, Legal Aspects of the Use of "Ordinary Simple Interest," 40 U. CHI. L. REv. 141, 141 
resulting in interest charges over the life of the loan of $\$ 2.56$ more than would have accrued under the $365 / 365$ method, ${ }^{19}$ a true yearly ineasurc. After discovering the overcharge, he filed a class action on behalf of himself and an estimated 50,000 similarly situated borrowers, ${ }^{20}$ claiming breach of contract and violation of Business and Professions Code section $17500 .^{21}$ He sought an injunction under section $17535^{22}$ and recovery of the overcharges, either under a breach of contract theory or by authority of section 17535 .

The trial court dismissed the class action. It found that the class neinbers were not readily ascertainable and that individual issues of law and fact would predominate over cominon ones because each borrower separately would have to prove his ignorance of the bank practice of charging in excess of the 365/365 rate. The trial court's decision was consistent with the traditional cominon law approach, and effectively limited the usefulness of section 17535 in advancing consumer remedies.

\section{B. The Court's Decision}

The supreine court upheld the trial court's dismissal of the class action as to the breach of contract claim. ${ }^{23}$ Following its earlier decision in Chern v. Bank of America, ${ }^{24}$ the court reasoned that, since a

(1972). Over the course of less than a year, e.g.., in the case of a six-month loan, the 360/360 method can result in some minimal distortion to the extent that the six months involved contain more or less than 182 1/2 days. Cf. id. at 142 \& $\mathrm{n} .3$ (365/360 method will produce more distortion in some six-month periods than others).

The $365 / 360$ method is calculated by dividing the stated interest rate by 360 to obtain the daily rate. Again the interest due is calculated: daily rate times principal times number of days in the payment period. Thus, the extra five days of interest in a full year will inean the effective interest rate exceeds that stated by $1 / 72$. Id. at 141-42.

Only the $365 / 360$ method was explicitly condemned by the court in Chern v. Bank of America, 15 Cal. 3d 866, 870, 544 P.2d 1310, 1312, 127 Cal. Rptr. 110, 112 (1976), though the language and reasoning of that decision could be expanded to forbid the $360 / 360$ method as well, at least for fractions of years. Id. at 876, 544 P.2d at 1316, 127 Cal. Rptr. at 116.

19. 23 Cal. 3d at 447, 591 P.2d at 54, 153 Cal. Rptr. at 31.

20. Not all borrowers are consumers who took out small loans. The class should include both corporations and some governmental bodies. Discovery revealed evidence that the average individual claiin would be $\$ 340$. Supplemental Brief for Appellant at $4-5$. Some borrowers might have had claims of well over $\$ 1,000$.

21. See note 13 supra.

22. See text accompanying notes $14-15$ supra.

23. Justice Clark explicitly agreed with the majority on this point. $23 \mathrm{Cal}$. $3 \mathrm{~d}$ at 459,591 P.2d at 62,153 Cal. Rptr. at 39. Justice Richardson did not address the breach of contract claim, but, as the author of the Chern opinion, he no doubt agreed with the majority.

24. 15 Cal. 3d 866, 544 P.2d 1310, 127 Cal. Rptr. 110 (1976). Accord, Payne v. United Cal. Bank, 23 Cal. App. 3d 850, 855, 100 Cal. Rptr. 672, 676 (1st Dist. 1972) (statute limited by its terms to injunctive relief). Chem presented the identical fact situation, with one exception. The plaintiff in Chem signed two forms: the bank's promissory note, with a stated interest rate of nine percent (the 365/360 inethod), and a federal Truth-in-Lending Statement, which declared the 
borrower's prior knowledge of the banking practice would defeat a breach of contract claim, ${ }^{25}$ and since many of the borrowers probably knew of the practice, ${ }^{26}$ each class member's individual knowledge of the practice would have to be hitigated. Accordingly, the court held that dismissal of the contract claim as a class action was a proper exercise of the trial court's discretion.

However, the court reversed the dismissal of the class action for restitution under section 17535. It first concluded that Chern, although a nearly identical challenge to the $365 / 360$ method, was not dispositive, since in that case only a claim for "damages," not "restitution," had been considered. ${ }^{27}$

Identifying the remedy sought in Fletcher as restitution rather than damages did not settle the issue, however, because prior to the 1972 amendment section 17535 contained no plainly restitutionary language. Fortunately for plaintiff, in People v. Superior Court (Jayhill) ${ }^{28}$ the court had already held, on different facts, that the post-1972 restitutionary language did not create a new rennedy, but merely clarified the status of the preexisting equitable remedy of restitution. ${ }^{29}$

annual interest rate to be $91 / 4 \%$. Chern was puzzled by the difference, and asked about it. After it was explained, Chern protested, but signed the forms and took out the loan. $15 \mathrm{Cal} .3 \mathrm{~d}$ at 870 , 544 P.2d at 1312, 127 Cal. Rptr. at 112.

25. Because of the rule that contemporaneous written instrninents are to be construed together, the Chern court held that the named plaintiff, and all other class nnembers who signed similar sets of forms, contracted for interest calculated by the $365 / 360$ inethod, and had no breach of contract claim. 15 Cal. 3d at 873-75, 544 P.2d at 1314-15, 127 Cal. Rptr. at 114-15. See note 57 infra.

26. It was an "industry-wide banking practice." $23 \mathrm{Cal} .3 \mathrm{~d}$ at $445,591 \mathrm{P} .2 \mathrm{~d}$ at 53, $153 \mathrm{Cal}$. Rptr. at 30. See Comment, Legal Aspects of the Use of "Ordinary Simple Interest," supra note 18, at 142.

27. $23 \mathrm{Cal}$ 3d at 448,591 P.2d at 55, 153 Cal. Rptr. at 31. In Chern, plaintiff's action to recover damages for violations of $\$ 17500$ was summarily disınissed: "Tlie applicable statutes do not authorize recovery of damages by private individuals. Private relief is limited to tle filing of actions for an injunction (id., \& 17535)." 15 Cal. 3d at 875, 544 P.2d at 1315, 127 Cal. Rptr. at 115. Since Chern's action was also filed before the effective date of the 1972 anendments, this too was a construction of $\S 17535$ before the amendment that clearly authorizes restitution. The reviewing standard for deciding whether plaintiff's complaint can survive a demurrer is whether it states facts that set forth any cause of action at all, not whether it sets forth the cause of action sought (here, "restitution" rather than "daunages"). Rosemead Co. v. Shipley Co., 207 Cal. 414, 420, 278 P. 1038, 1041 (1929). Hence, it cannot be correct to say that Chern is not on point. The majority would have done better to admit they were overruling a perliaps hasty decision in Chern on the statutory restitution claim.

Justice Riclıardson, joined by Justice Manuel, dissented strongly on this issue, pointing to the authority of Chern. $23 \mathrm{Cal}$. 3d at 455, 591 P.2d at 59-60, $153 \mathrm{Cal}$. Rptr. at 36.

28. 9 Cal. 3d 283, 507 P.2d 1400, 107 Cal. Rptr. 192 (1973).

29. Id. at 287 n.l, 507 P.2d at 1402 n.l, 107 Cal. Rptr. at 194 n.l. In Jayhill, the Attorney General brought an action against door-to-door encyclopedia sellers, seeking an injunction and restitution under $\$ 17535$. The action liad been filed before the 1972 amendments. The court repeated the the general principle that a court of equity has considerable power to effect complete justice and declared, "In particular, in an action by the Attoruey General under section 17535 a trial court has the inherent power to order, as a form of ancillary relief, that the defendants make 
This brought the court to the dispositive issue in Fletcherwhether the trial court could order restitution to the class without individuahized proof by each class member of common law reliance, i.e., ignorance that the actual imterest rate charged differed from the advertised rate. The sections that follow will discuss the court's reasoning for its holding that such mdividualized proof of reliance is not necessary for class restitution.

Having determined that the trial court could allow the restitution claim class status, the supreme court remanded for trial court consideration as to whether im this case it should. To answer this question, the court suggested that the trial court consider whether an individual action under section 17535, which could also lead to restitution for the class, would be more appropriate. Such an individual action might avoid the costs of certification and notice to class members usually required in class actions. The court briefly suggested that in resolving this issue the trial court ought also to consider plaintiff's ability to represent adequately all the borrowers in an individual action. Part V of this Note will examine the procedural device of an individual action brought on behalf of a class.

\section{The Court's Analysis}

In order to decide whether imdividual proof of reliance was required, the court first looked to the language of the pre-1972 statute. Not finding explicit support there for an order of restitution to the Fletcher class, the court turned to the language of the 1972 amendment, following the questionable Jayhill explanation that the ainendinent simply clarifled the application of equitable restitution under the statute. $^{30}$ Whether or not this rationale is convincing as applied to the pre-

or offer to make restitution to the customers found to have been defrauded." 9 Cal. $3 \mathrm{~d}$ at 286,507 P.2d at 1402, 107 Cal. Rptr. at 194.

The explanation for the inconsistency between Jayhill and Chern probably lies in one of two sources. The appellate briefs submitted to the court in Chern all failed to mention $\$ 17535, b u t c f$, Johnson, Foreword: The Accidental Decision and How It Happens, 65 CALIF. L. Rev. 231, 249 (1977) (briefs' omission of important point usually will not affect outcome since the California Supreme Court's large staff is likely to detect it). Perhaps more significantly, as the facts of the Chern case were unfavorable to plaintiff's pursuit of any equitable relief, Chern's claims received scant judicial attention.

The California Supreme Court usually gives less deference to post-enactment "legislative history." See, e.g., People v. Tanner, 587 P.2d 1112, 1129-35, 151 Cal. Rptr. 299, 316-22 (1978) (Clark, J., dissenting) (plurahty ignores legislative history), rehearing granted and rev'd, 24 Cal. 3d 514, 538-50, 596 P.2d 328, 342-50, 156 Cal. Rptr. 450, $464-72$ (1979) (Newman, J., dissenting) (legislative history of hitle use; subsequent legislative history less useful than enacted will of legislature).

30. 'In light of [the 1972 amendment's] legislative history, we hold that the amendment was mtended not to create a new power in the trial court but simply to clarify existing law on the point." 9 Cal. 3d at 287 n.1, 507 P.2d at 1402 n.1, 107 Cal. Rptr. 194 n.1. The reference to 
1972 statute, Fletcher is important as an authoritative interpretation by the supreine court of the statute as it exists today.

The court concentrated on the amendment's provision that the trial court "inay inake such orders . . . as may be necessary to restore ... any money . . . which may have been acquired by means of any [unlawful] practice." The court inferred that, had the legislature wanted to restrict the power of the court so that it could only order restoration of money the loss of which was proximately caused by the unlawful practice, it would have indicated that intention by phrasing the same sentence without the words: "which may have been." This phrase might mean simply that the court could restore whatever money it found to have been deceitfully obtained, which would seem to require individual proof of loss. Another interpretation of these wordsthe one the court adopted-is that the trial court may order restitution whether or not the unfair practice actually caused any loss. Such an interpretation credits the phrase "may have been" with a conditional quality that would explain why the legislature chose those words over a more declarative form. ${ }^{31}$

An alternative reading of the statutory language, however, is that it is designed to shift the burden of proof on the question of consumers' knowledge. ${ }^{32}$ Once plaintiffs establish that the bank had engaged in an unfair trade practice, they would be presumed to be injured ${ }^{33}$ by the difference between the advertised and the actual interest rates, subject to rebuttal by the bank that borrowers had knowledge of the actual interest calculation method. Yet it seems unlikely that the legislature would have intended this to be the only effect of the statute, since in that case the statute would imadequately deter deceptive trade practices. Banks could merely plead the affirmative defense of borrower knowledge, put the federal Truth-in-Lending forms into evidence-which they could do for all plaintiffs who borrowed after July 1, 196934 - and thus force the plaintiffs to individual proof. The court would no more be able to allow the class action for restitution to go forward than it had the class action for breach of contract. In sum, the statute's restitutionary language might have meant at least three different things: a re-

legislative history is shaky. It parallels the argument in Comment, Fraudulent Advertising: The Right of a Public Attorney to Seek Restitution for Consumers, 4 PAC. L.J. 168, 177 (1973). Yet there the author's basis for that argument was a telephone interview with a committee consultant. Id. at 177 \& nn.69-73.

31. See Gaylord, An Approach to Statutory Construction, 5 Sw. U.L. REv. 349, 373 \& n.120 . (1973) (canon of statutory construction suggests that best construction is one giving effect to all parts of a statute).

32. See Cleary, Presuming and Pleading: An Essay on Juristic Immaturity, 12 STAN. L. REv. 5, 11-12 (1959).

33. Cal. Evid. Code $\$ 605$ (West Supp. 1979).

34. See note 57 infra. 
quirement for individual proof of reliance before restitution could be granted, judicial discretion to enforce strict liability for any unfair price differential once the defendant's conduct was found to be "deceptive," or a rebuttable presumption of harm to all members of the class. All three are plausible, considering the linguistic ambiguity and the absence of legislative history on the point. The court's rather facile choice of the second reading may be explaimed by the court's adherence to a policy of enforcing "the prescribed strong deterrent." 35

In addition to its language analysis, the court argued that since section 17535 is based on general equitable principles, ${ }^{36}$ the trial court has broad power to order whatever relief seems just, including restitution, without proof of individual lack of knowledge. ${ }^{37}$ Its support for this statement is not convincing; it inerely cited previous declarations that a court of equity has broad powers, and can order restitution if appropriate. ${ }^{38}$ This approach, moreover, ignores the fact that a court of equity could never order restitution to a plaintiff who knew of and understood an allegedly deceptive practice. ${ }^{39}$

The court found additional support for its holding in its third and inost persuasive argument, which relied on the public policy ${ }^{40}$ of condemnation of deceptive practices, whether successful in deception or not. By analogy to federal securities law under which a trader who misrepresents or suppresses a material fact is forced to disgorge all possibly tainted profits, ${ }^{41}$ the court argued that a law that at most restores the status quo between the unfair competitor and only those consumers who will come forward and can individually prove reliance will not discourage unfair practices nearly as much as a more costly sanction.

The problem, though, is that the court made a procedural argu-

35. 23 Cal. $3 \mathrm{~d}$ at 450,591 P.2d at 56, 153 Cal. Rptr. at 33.

36. Resort to the maxims of equity, see, e.g., CAL. Civ. Code $\$ \S 3509-3548$ (West 1973), is inapposite since most, if not all, equitable principles are designed for the case where one or a himited number of plaimtiffs before the court is suing one or a limited number of defendants. The majority seems to reach its conclusion because of syinpathy for consumers' difficulties in suing institutions. Thus, Justice Richardson's apprehension, im his dissent, that the majority has opened the door to undeserving suits by comnercial borrowers fully aware of some uncondemned industry-wide banking practice, is not well grounded, as such suits could be readily distinguished from the Fletcher holding.

37. 23 Cal. $3 d$ at 452,591 P.2d at 57-58, 153 Cal. Rptr. at 34.

38. See McClenny v. Superior Court, 62 Cal. 2d 140, 148, 396 P.2d 916, 921, 41 Cal. Rptr. 460, 465 (1964); Snelson v. Ondulando Highlands Corp., 5 Cal. App. 3d 243, 258, 84 Cal. Rptr. 800, 809 (2d Dist. 1970). See also Porter v. Warner Holding Co., 328 U.S. 395, 402 (1945).

39. See, e.g., Restatement of Restitution § 64, Illustrations 6-10 (1937). See also CaL. CIv. CODE $\S 3516$ (West 1970) ("Acquiescence in error takes away the right of objecting to it."). 116.

40. See, e.g., Chern v. Bank of America, 15 Cal. 3d at 876, 544 P.2d at 1316, 127 Cal. Rptr. at

41. See SEC v. Texas Gulf Sulphur Co., 446 F.2d 1301, 1307-08 (2d Cir.), cert. denied, 404 U.S. 1005 (1971). 
ment, with support from cases that decided procedural matters, for a decision that is actually substantive. The court cited Daar v. Yellow $\mathrm{Cab} \mathrm{Co.}{ }^{42}$ for the proposition that "a class suit [is a preferred] procedure that would permit the allegedly injured parties to recover the amount of their overpayments," ${ }^{43}$ thereby suggesting that Fletcher, hike Daar, merely makes it possible to consolidate in one proceeding the trial of the elements that would otherwise have to be shown in many mdividual actions. Yet Fletcher does mucli more. It changes the substantive basis of liability by an interpretation of the law of this statutory tort to add damages of an effectively punitive nature as a remedy against deceptive advertising. The court's substantive holding can be defended, but only by resort to the additional policy considerations discussed in the next section.

\section{III}

\section{Public Policy Basis for Restitution Without RELIANCE}

Restitution without proof of individual reliance should be allowed, although it would perhaps be better labelled statutory damages so that the concept of restitution is not distorted. Three basic policy choices are possible. The first is to allow damages only upon proof of reliance, as the trial court ordered. The result of this solution is easy to foresee: few, if any, of the 50,000 borrowers would sue individually for the overpayment. No class action could be maintained. Even for most of those imdividuals whose claims were relatively large, and who were aware of their cause of action, it is unlikely that the amount of the possible recovery would justify bringing suit. ${ }^{44}$ Thus, the threat of private actions would offer little dismcentive to violations of the statute. And the public remedy, e.g., the occasional suit by the Attorney General for an imjunction or restitution, would be unlikely to deter unlawful conduct sufficiently. ${ }^{45}$ Requiring individual proof of reliance, then, would mean that section 17535 would not effectively prevent consumer fraud.

A second solution-one for which Fletcher could arguably be read-would be to give plaintiff full recovery upon proof of the unfair trade practice or similar violation, without any requirement of proof of

42. 67 Cal. 2d 695, 433 P.2d 732, 63 Cal. Rptr. 724 (1967).

43. 23 Cal. 3d at 452,591 P.2d at 57, 153 Cal. Rptr. at 34 (quoting 67 Cal. $2 d$ at 715,433 P.2d at 746,63 Cal. Rptr. at 738).

44. McCall, Due Process and Consumer Protection: Concepts and Realities in Procedure and Substance-Class Action Issues, 25 HASTINGS L.J. 1351, 1363 \& n.68 (1974).

45. See Vasquez v. Superior Court, 4 Cal. 3d at 817 n.14, 484 P.2d at 974 n.14, 94 Cal. Rptr. at $806 \mathrm{n} .14$. 
reliance. This strict approach to disgorging all unlawful profits would have the advantage of guaranteeing inore severe penalties which would likely have a greater inhibitory effect. The disadvantage, though, of removing trial court discretion in the size of dainage awards would be the unevenness of justice that would occur, since the less culpable would be as liable as the completely culpable. For example, a bank that loaned inoney primarily to corporations whose officers knew of the $365 / 360$ method and who understood it to be customary business practice would lave to refund the sane proportion as another bank that only made personal loans to unwary consumers, since Chern estabhished that the inetlod itself is deceptive. In analogous situations, the trend seeins to favor deterrence despite the risk of rewarding undeceived plaintiffs. ${ }^{46}$

The argument for the second alternative-strict liability to disgorge unfair gains-is enhanced by consideration of two other doctrines that indicate the particularly appropriate factors courts should analyze in such cases. The rationale underlying the doctrine of implying a private right of action from a consumer protection statute supports restitution without proof of reliance. In J.I. Case v. Borak ${ }^{47}$ the United States Supreme Court held that there was a private right of action for violation of the proxy requirements of the Securities Exchange Act of 1934. The court observed that, as the chance of enforcement by the SEC was small, and the threat of civil dannages and injunction was a "inost effective weapon" in enforcement, "it is the duty of the courts to be alert to provide such reinedies as are necessary to inake effective the congressional purpose." $" 48$ In Fletcher the private right to seek an injunction is explicit. However, this is not sufficient, as the injunction remedy alone provides no incentive for private parties to pursue it. If the legislative purpose in enacting section 17535 is to be realized, the private right to seek disgorgenent of profits should be recognized.

Similarly, the California Supreme Court in Serrano v. Priest ${ }^{49}$ has recognized the "private attorney general" theory as a means to promote litigation in the public interest. ${ }^{50}$ The hesitation in Serrano to extend

46. See Comment, The Demise of In Pari Delicto in Private Actions Pursuant to Regulatory Schemes, 60 CALIF: L. REv. 572, 572 (1972).

47. 377 U.S. 426 (1964).

48. Id. at $432-33$.

49. 20 Cal. 3d 25, 569 P.2d 1303, 141 Cal. Rptr. 315 (1977).

50. "[I]t frequently occurs that citizens in great numbers and across a broad spectrum have interests in common . . . of enormous significance to the society as a whole [that] do not involve the fortunes of a single individual to the extent necessary to encourage their private vindication in the courts. . . . The firms [who will represent these interests] are not funded to the extent necessary for the representation of all such deserving interests, and as a result many worthy causes of this nature are without adequate representation under present circumstances. One solution, .... is the award of substantial attorneys fees to those public-interest litigants and their attorneys . . .." 
the applicability of the "private attorney general" theory so that it would clearly cover Fletcher-type cases was not because of any fear that it was poor public policy, but because of respect for the legislative role in policymaking. ${ }^{51}$ The Serrano court left open the question of the applicability of the theory to suits brouglit on statutory grounds, ${ }^{52}$ since that suit concerned constitutional riglits. Here, in Fletcher, the court faced the private attorney general theory as applied to a statutory sclieme of enforcement. The court cliose not to mark off a rigid demarcation between legislative and judicial powers, but to use the judicial power to effectuate the legislative purpose. In view of the practical difficulties of maimtaining a class action, the court should properly prefer the disgorgement remedy to the alternative of requiring individual proof.

Still a third option-a more efficient and just middle ground-may be what the court meant by the undefined phrase "trial court discretion." The trial court may, but need not always, award "restitution" im the full amount of the class members' theoretical harm. This approacl would give the trial court sufficient power to effectuate the deterrent force the statute was intended to have, ${ }^{53}$ while retaining the court's ability to do justice between the parties before it, recognizing that in fact many class members, i.e., tliose wlio bargained knowledgeably, ought not to be given restitution. Read thus, the statute would allow and encourage tlie ordering of restitution in the amount most likely to achieve botli goals.

After a violation has been proven, the court slould award the plaimtiffs an amount calculated.after examining the relative culpability of the defendant's activities, the sophistication of its clientele, and the profitability of the deceptive practices, subject to a limitation that the amount awarded could not exceed the maximum amount of potential claims for restitution. Taking into account these factors, the restitution

Id. at 44,569 P.2d at $1313,141 \mathrm{Cal}$. Rptr. at 325.

51. Id. at 46,569 P.2d at $1314-15,141$ Cal. Rptr. at 326 .

52. Id. at 47,569 P.2d at 1315,141 Cal. Rptr. at 327.

53. Justice Richardson, dissenting, thought that the statute's use of "necessary," see text accompanying note 15 supra, meant "essential." $23 \mathrm{Cal} .3 \mathrm{~d}$ at 455-56, 591 P.2d at 60, $153 \mathrm{Cal}$. Rptr. at 35. This is, however, an ill-considered argument, since the more common interpretation of "necessary" over the years has been that it meant "appropriate." See Danley v. Merced Irrigation Dist., 66 Cal. App. 97, 105, 226 P. 847, 850 (3d Dist. 1924). See also Los Angeles Fin. Co. v. Flores, 110 Cal. App. 2d Supp. 850, 852, 243 P.2d 139, 141 (1952). See generally Marbury v. Madison, 5 U.S. (1 Cranch) 137 (1803); FED. R. CIV. P. 19. Certainly, "appropriate" better accords with the other discretionary language in the sentence. Even if "essential" were a correct interpretation of the meaning of "necessary," the rest of Justice Richardson's argument is doubtful, since it assumes that the deterrent purpose of the statute is fully effectuated by the injunction remedy. Actually, an imjunction effectively deters only future violations by parties to the suit; there is not nearly as inuch deterrent effect for other banks, and even less for other possible violators of the statute. 
ordered should be set at an amount such that, for a rational business of that type, the percentage chance of being caught multiplied by the cost if caught will exceed the expected profits from false advertising. ${ }^{54}$ This should deter rationally managed businesses froin false advertising. Alternatively, the award of restitution should at least be set in sufficient amount so that the plamtiff's attorney recoups his or her fees ${ }^{55}$ and is encouraged to bring further meritorious suits.

\section{IV}

\section{IMPLICATIONS OF FLETCHER}

The majority's resort in Fletcher to policies of substantive law should be seen as a recognition that the class action device had stalled ${ }^{56}$ in the area of consumer protection. ${ }^{57}$ If in the future consumer protec-

54. See generally McCall, supra note 44 , at 1369-78.

55. See text accompanying note 91 infra.

56. The court's decision appears to offer a way out of the ambiguities that have arisen over maintenance of class actions. In recent years, in Blue Chip Stamps v. Superior Court, 18 Cal. 3d 381, 556 P.2d 755, 134 Cal. Rptr. 393 (1976) (4-2-1 decision) (two justices concurred in the result but disowned the majority's reasoning), and City of San Jose v. Superior Court, 12 Cal. 3d 447, 525 P.2d 701, 115 Cal. Rptr. 797 (1974) (4-3 decision), a narrow majority appeared to be reversing the court's trailblazing path in Daar and Vasquez in favor of class actions generally and consumer class actions in particular. See The Supreme Court of California 1976-1977, 66 CALIF. L. REv. 178, 233 (1978). These cases were all decided on what were technically procedural grounds, though the substantive issues had never been far from the surface.

57. The court's decision to uphold the dismissal of the class action breach of contract claim was correct but needlessly overbroad in its reasoning. This may be explamed either by the sufficiency in this case of the remedy under $\S 17535$, or by a concern with the limitations in general of class actions. Thus, the court foreclosed an exploration of the possibilities and problems of extending the class action device to the limit. Moreover, the procedural posture of the case restricted the court, since it could only reverse if it found that the lower court had abused its discretion.

The Fletcher court's restatement of Chern's breach of contract holding is overdrawn. Fletcher borrowed before July 1, 1969, 23 Cal. 3d at 446, 591 P.2d at 54, 153 Cal. Rptr. at 30, the effective date of the federal Truth-in-Lending Act, 34 Fed. Reg. 2002 (1969), while Chern borrowed after that date. $15 \mathrm{Cal} .3 \mathrm{~d}$ at $870,544 \mathrm{P.2d}$ at 1312, $127 \mathrm{Cal}$. Rptr. at 112. All borrowers after July 1, 1969, should have signed a federal Truth-in-Lending statement, 12 C.F.R. \$226.6(i)(2) (1979) (stating 1969 effective date), in addition to the bank's own forms.

All potential plaintiffs therefore fell into two categories, $c f$. City of San Jose v. Superior Court, 12 Cal. 3d at 466, 525 P.2d at 714, 115 Cal. Rptr. at 810 (Tobriner, J., dissenting) (suggesting subclasses might be appropriate where the class is ununanageable). Borrowers like Chern cannot collect damages because their agreements, which included disclosure of computation method, can all be interpreted as incorporating the bank's $365 / 360$ practice. Borrowers like Fletcher, on the other hand, have a prima facie claim for breach of contract, though the bank has possible defenses to some of the clamis, such as industry custom; the bank might also try to argue the ambiguity of the term "per annum." 1 B. Witkin, Summary of California Law, Contracts $\$ 534$, at 456 (8th ed. 1973). Whether or not these defenses should be allowed to defeat the class status of the pre-July 1, 1969 borrowers is a close question, which the Fletcher court did not seein to recognize.

Still another possible approach to the contract clamis is worthy of note, though it is unprecedented in California. The United States Court of Appeals for the Second Circuit in some 10b-5 securities cases, exemphified by Green v. Wolf Corp., 406 F.2d 291 (2d Cir. 1968), cert. denied, 395 
tion law is decided in substantive rather than procedural terms, that will aid the delineation and quality of argument, forcing a sharper analysis of the issues. ${ }^{58}$

The decision should also mcrease the effectiveness of the Consumers Legal Remedies Act (CLRA), ${ }^{59}$ the latest addition to the statutory protection of consumers. In this case it provided no relief, ${ }^{60}$ simce Fletcher borrowed before its effective date of January 1, 1971.61 The CLRA's substantive and procedural provisions are designed to protect consumers. ${ }^{62}$ Its provisions contain three significant innovations: (1) they heavily emphasize settlement, which inust be atteinpted before any remedy other than an mjunction may be sought; ${ }^{63}$ (2) as an encouragement to settlement, they increasingly favor plaintiffs, in that the court may order either party to bear the costs of notice if the suit is a class action; ${ }^{64}$ and (3) they allow not only damages and an injunction, but also pumitive damages and "[a]ny other relief which the court deems proper."65 The general design of the statutory provisions evinces an attempt to use the threat of possibly severe sanctions to enforce out-of-court settlements. This is thought to further the two policy goals of lessening the burden on the courts ${ }^{66}$ and inore effectively discouraging the occurrence of deceptive advertising.

The trial court's discretion to permit a class action absent individual proof of rehance, which the court found in section 17535, complements the other remedies the CLRA provides. Fletcher itself demonstrates how such power is useful when a class action could not

U.S. 977 (1969), has recognized that a class action under 10b-5 could proceed even though each class meunber had to show reliance, since this could be dealt with in the separate individual hearings which would be necessary in order to prove danages for each clainant anyway. While such a solution is cunbersome, it should be considered, at least in those situations where allegedly wronged plaintiffs have no reınedies otherwise.

58. See Hazard, The Effect of the Class Action Device Upon the Substantive Law, 58 F.R.D. 307 (1973); Comment, The Impact of Class Actions on Rule 10b-5, 38 U. CH1. L. REv. 337 (1971).

59. Cal. Civ. Code $\$ \S 1750-1784$ (West 1973 \& West Supp. 1979).

60. The bank's practice probably would be covered by CAL. CIV. CODE $\$ 1770(i)$ (West Supp. 1979) (prohibits advertising of services with intent not to sell them as advertised). A future Fletcher can pursue this remedy in addition to his other ones. Despite the attractiveness of the possibility of putting notice costs on the defendant, the same hurdles to inaintaining a class action would have to be surmounted as under $\$ 17535$. For a discussion of why a future plaintiff in Fletcher's position might not sue under the CRLA, see Note, Cartt v. Superior Court: Notice and Consumer Class Actions in California, 64 CALIF. L. REv. 1222, 1227 n.33 (1976).

61. Cal. Civ. Code $\$ 1756$ (West 1973).

62. Id. $\$ 1760$ (West 1973). See Reed, Legislating for the Consumer: An Insider's Analysis of the Consumers Legal Remedies Act, 2 PAC. L.J. 1, 8 (1971).

63. CaL. Civ. Code $\$ 1782$ (West 1973).

64. Id. $\S 1781$ (d). The court inay also require less than personal notification, if that is "unreasonably expensive." $I d$.

65. Id. \$1780.

66. $C f$. Reed, supra note 62 , at 17 (statutory settlement procedure gives all businesses the opportumity to inake consuiners whole without going to court). 
be maintamed if the trial court were limited to the express remedies. Moreover, the possibility of having to pay restitution adds pressure to settle. Some class actions that would not have been brought, or would have been brought only as individual actions because they did not present a credible threat of being maintamable without this new interpretation, will now be prosecuted.

Plaintiffs' lawyers will increasingly face the problem of how to represent fully the imterests of all class members. ${ }^{67}$ For exainple, the Fletcher plaimtiffs may not have uniform interests. Some of the plaintiffs have a right of recovery under a breach of contract theory as well as the section 17535 restitutionary theory. Others in the class depend solely on section 17535 for any recovery. If a successful action could result in a much larger recovery under one theory than the other, then there might be a conflict of interest, since some class meinbers might want to pursue the more difficult breach of contract claim, whereas others would not. In Fletcher, the evidence tended to show that the average claim for each of the 50,000 class members would only be somewhat in excess of $\$ 300 .{ }^{68}$ If some of the claims were much larger than the average, then some of the class might prefer to pursue those claims separately.

In such a case as this one, then, if plaintiff is to avoid the possibility of having to pay the costs of notice to some class meinbers who may prefer other remedies anyway, plaintiff may have to limit the class to a subclass of the original one; for example, only those borrowers whose damages are alleged to be less than a fairly modest figure, say, $\$ 200$ or $\$ 300$. In spite of the improbability that those with greater claims would ever brimg suit, that possibility highlights the main issue for the trial court. It must weigh those possible plamtiffs' due process right to a day in court on the breach of contract claim, ${ }^{69}$ which will be lost if the class brimgs the restitution claim, ${ }^{70}$ agamst the defendant's interest in avoiding litigation with a high potential for offensive, but not defensive, collateral estoppel. ${ }^{71}$ The second threat is more likely to be realized if the class includes members who have sizable breach of contract claims, and recovery under section 17535 is much less than would be under the contract claims. If this happens, those members may be inadequately represented, and therefore should not be bound by the judginent.

One other problem that may arise from the court's opinion is

67. See ABA Code of Prof. Resp., EC 5-14, EC 5-15, EC 5-16, EC 5-19 (Final Draft, 1969).

68. Supplemental Brief for Appellant at 4-5.

69. Milliken v. Meyer, 311 U.S. 457,463 (1940).

70. Olwell v. Hopkins, 28 Cal. 2d 147, 152, 168 P.2d 972, 975 (1946).

71. Parklane Hosiery Co. v. Shore, 439 U.S. 322, 331 (1979). 
whether the holding as to nonreliance extends to individual actions for individual recovery. ${ }^{72}$ While the holding is ambiguous because it does not discuss such actions, the reasoning of two of the three arguments ${ }^{73}$ supports extension of it to them under section 17535 as amended. Such an extension, while logical, seems unfair; the individual action has little or no enforceinent or deterrent effect, unlike the class action. Recovery in individual actions, absent proof of reliance, serves no public policy and provides a windfall for plaintiff. Nevertheless, its unfairness is more apparent than real, since the size of the award is within the trial court's discretion. Thus, an action for settlement value is unlikely to commend itself to the consumer when defendant's conduct is unlawful but not opprobrious, ${ }^{74}$ because the settlement value is likely to be sinall.

\section{V \\ The Individual Action for Class Recovery Under SECTION 17535}

The court suggested that the trial court might still dismiss the class action because section 17535 gives named plaintiff authority to seek restitution to the class as ancillary relief in an individual action seeking an mjunction. ${ }^{75}$ Plaintiff could thereby avoid the potentially great costs of notice and certification. However, the court further suggested that a possible objection to the individual action is that plaintiff might be less likely to represent the class adequately than he would in a class action. ${ }^{76}$ Justice Clark, dissenting, argued that the individual action offered many benefits over the class action, without any of the claimed disadvantages, so that a class action in this case, and presumably in any action under section 17535 , is of no benefit to either the litigants or the court and should not be allowed. ${ }^{77}$

Resolution of this colloquy hinges on the differences between an individual action for class recovery under section 17535 and a true class action. There are four ways they might differ: in the effect of the suit on absent class members; in fairness to the defendant; in convenience

72. For a discussion of individual actions for class recovery, see text accompanying notes 7591 infra.

73. See text accompanying notes $30-31$ and $40-41$ supra. It is inconsequential that the equity argument, see text accompanying notes 36-39 supra, does not support it, since that argument only applies to the statute before amendment.

74. Cf. American Timber \& Trad. Co. v. First Nat'l Bank, 511 F.2d 980, 985 (9th Cir. 1974) (concurring opimion) ( $365 / 360$ inethod may be misleading, but it is not coinparable to loan sharkmg).

75. 23 Cal. 3d at 454, 591 P.2d at 59, 153 Cal. Rptr. at 35.

76. Id. at $454,591 \mathrm{P} .2 \mathrm{~d}$ at $59,153 \mathrm{Cal}$. Rptr. at 34.

77. Id. at 456-59, 591 P.2d at 60-62, 153 Cal. Rptr. at 36-38. 
to the court; and in the chances that the suit will be pursued at all. Examination of these factors shows that there are few, if any, operational differences between an individual action for class recovery and a class action not requiring individual notice.

An individual action does not bind absent class members, ${ }^{78}$ although in many cases absent class members can take advantage of a favorable verdict through the offensive use of collateral estoppel. ${ }^{79} \mathrm{~A}$ class action, by contrast, bimds absent class members. ${ }^{80}$ However, strict adherence to such clear-cut distinctions has decreased. For example, in the recent case of Cartt v. Superior Court, ${ }^{81}$ the court of appeals allowed a consumer class action to proceed without individual notice to all class members, even though those not notified might not be bound by the judgment. The court stated that subsequent suits attacking the judgment would trigger "a more careful scrutiny of its representative charac" $t e{ }^{\prime \prime 82}$ to determine whether it could be given res judicata effect. The determination of whether a class action or other representative suit ${ }^{83}$ will bind absent class members depends, not on notice, but on whether "they are in fact adequately represented by parties who are present." One difference, therefore, between a class action and an individual action under section 17535 is that a judgment im the latter binds only as a practical matter, not a legal one. An individual action under section 17535 would be akin to, if not mdistinguishable from, a Cartt class action.

Fairness to the defendant also depends on the res judicata effects of the class or individual action. Yet from this poimt of view both types of action are about equally fair to the defendant. The class action informs him of the extent of his potential liabihty, and allows him to make a rational judgment as to how best to protect his interests. ${ }^{85}$ In an individual action on behalf of a class, if named plaimtiff adequately represents the class, then the judgment should likewise bind the class members. ${ }^{86}$ Even if it does not, the practical effect of a judgment adverse to the class will be to discourage seriously any further attempt by

78. Blonder-Tongue Lab.'s, Inc. v. University of Ill. Found., 402 U.S. 313, 329 (1971); Bernhard v. Bank of America, 19 Cal. 2d 807, 812, 122 P.2d 892, 894 (1942).

79. Parklane Hosiery Co. v. Shore, 439 U.S. 322, 331 (1979).

80. Hansberry v. Lee, 311 U.S. 32, 41 (1940).

81. 50 Cal. App. 3d 960, 124 Cal. Rptr. 376 (2d Dist. 1975).

82. Id. at 971,124 Cal. Rptr. at 384 (italics in original). Cf. Gonzales v. Cassidy, 474 F.2d 67

(Sth Cir. 1973) (two-part test required in determining representative character of proceedings).

83. E.g., derivative suits. See Fed. R. Clv. P. 23.1.

84. Hansberry v. Lee, 311 U.S. at 43.

85. Cf. Parklane Hosiery Co. v. Shore, 439 U.S. at 300 ("a defendant [in an individual action who] is sued for small or nominal damages . . . may have little incentive to defend vigorously, particularly if future suits are not foreseeable.").

86. Restatement (SeCond) of Judgments $\S 85(1)$ (e) \& (2) (Tent. Draft No. 2, 1975). 
other plaintiffs to litigate the issue. ${ }^{87}$

Convenience to the court involves one concern: How can the issues raised in the suit be settled with the least use of judicial resources? Either a class action or an individual action on behalf of a class is likely to involve lengthy pre-trial inaneuverings, appeals of trial court rulings, ${ }^{88}$ and other delays. Either can be challenged collaterally as to the adequacy of representation of absent parties. Since as a practical inatter the individual action binds absent parties, both types of action should involve an approximately equal claim on judicial resources.

Whether it is easier for nained plaintiff to pursue an individual action or a class action depends upon how the adequacy of plaintiff's representation is to be decided. If plaintiff adequately represents the class, then the real issue, unaddressed by the Fletcher court, is not what form the action takes, but rather what notice, if any, is required for the class action to proceed and for the judginent to be binding. The California Suprenue Court has thus far been unwilling to address these two issues $^{89}$ in either the context of a class action or of an individual action with class recovery.

When the court finally decides this question, it should look to the reality, not the appearance, of due process. The reality of a true consumer class action, in which no individual plaintiff has a claim worth pursuing singly, ${ }^{90}$ is that the party with the inost direct economic interest is plaintiff's attorney. ${ }^{91}$ Whether there is a judgenent for or against the class is practically irrelevant as far as the individual economic interests of the class inembers are concerned, since, in either type of action, the benefits are likely to be only those that flow to the public generally from condemning and deterring unlawful conduct. In effect, plaintiff's attorney, notivated by either hope of monetary gain or concern for the "public interest," or both, prosecutes a suit whicli benefits the public by enforcing a regulatory scheine adopted by the legislature. In this situation, the duty of the judiciary is to ensure that the plaintiff's attorney is

87. Cartt v. Superior Court, 50 Cal. App. 3d at 969,124 Cal. Rptr. at 382.

88. An unfavorable ruling or decision is so potentially costly to either plaintiff or defendant that an appeal will almost always be a wise investunent by the losing party.

89. See People v. Pacific Land Research Co., 20 Cal. 3d 10, 18 \& n.8, 569 P.2d 125, 130 \& n.8, 141 Cal. Rptr. 20, 25 \& n.8 (1977) (Attorney General's right to pursue, without notice, $\$ 17535$ remedies, including restitution, held not violative of defendant's due process rights; no determination as to defendant's rights if the action is brought by an individual); Cartt v. Superior Court, 50 Cal. App. 3d at 976, 124 Cal. Rptr. at 376 (hearing denied).

90. Discovery revealed evidence tending to show that the average individual claim in Fletch$e r$ would be $\$ 340$. Supplemental Brief for Appellant at 4-5. Hence Justice Tobriner's admonition to the trial court should be interpreted to inean that, whether the action is individual or class, some individual notice to those with potentially large claims should be required, in order to insure that named plaintiff and his counsel will adequately represent their interests, too.

91. Dam, Class Action Notice: Who Needs It?, 1974 SuP. CT. REv. 97, 121; Degnan, Foreword: Adequacy of Representation in Class Actions, 60 CALIF. L. REv. 705, 715 (1972). 
faithful to the regulatory scheme. The primary instrument of control should be the discretion to award costs and attorney's fees and to supervise and approve settlements.

\section{CONCLUSION}

The decision to allow restitution without a showing of individual reliance on deceptive representations in class actions under Busmess and Professions Code section 17535 increases available consumer remedies and therefore the incentives for private enforcement of the legislature's protective scheme. Fletcher is probably best understood in the context of a faith in judicial activism, as its holding will place great responsibilities in the discretion of trial judges.

Fletcher's significance hes in two possibilities it suggests for consuiner actions. What importance they will attain remaims to be seen, as their implententation depends on trial court discretion. Section 17535 suits now have the potential to be used by trial courts as fairly precise instruments for recovering wrongfully obtamed profits from unscrupulous business defendants, putting teetl in the statutory scheme to deter misleading claims or deception in the marketplace. The supreme court's apparent ratification of Cartt-type class actions and individual injunctive actions with potential for class restitution suggests litigation tactics which could avoid the high costs of notice tliat have impeded substantively well-grounded consumer class actions.

Richard G. Andrews*

* B.A. 1977, Haverford College; third-year student, Boalt Hall School of Law. 